\title{
Reproduction in Heteroteuthis dispar (Rüppell, 1844) (Mollusca: Cephalopoda): a sepiolid reproductive adaptation to an oceanic lifestyle
}

\author{
H. J. T. Hoving • V. Laptikhovsky • \\ U. Piatkowski · B. Önsoy
}

Received: 9 July 2007 / Accepted: 16 January 2008 / Published online: 2 February 2008

(C) The Author(s) 2008

\begin{abstract}
Small cephalopods of the genus Heteroteuthis are the most pelagic members in the family Sepiolidae. This study examines the reproductive biology of Heteroteuthis dispar (Rüppell, 1844), the first such study on any member of the genus, based on 46 specimens (27 females and 19 males) collected during the Mar-Eco cruise in the North Atlantic in the region of the Mid-Atlantic Ridge in 2004, and compares it with reproductive features in the less pelagic members of the family. The unusually large spermatophores of the males have a very small ejaculatory apparatus and cement body, relative to the size of the sperm mass. Females first mate when they are still maturing: a large sperm mass (up to $3.4 \%$ of the female body mass), consisting of one to several spermatangia, was found in an
\end{abstract}

Communicated by P.W. Sammarco.

H. J. T. Hoving $(\bowtie)$

University of Groningen, CEES,

Ocean Ecosystems, P.O. Box 14,

9750 AA, Haren, The Netherlands

e-mail: H.J.T.Hoving@ rug.nl

V. Laptikhovsky · B. Önsoy

Falkland Islands Fisheries Department,

Stanley QQ 1ZZ, Falkland Islands

V. Laptikhovsky

e-mail: VLaptikhovsky@ fisheries.gov.fk

B. Önsoy

e-mail: thysanoteuthis@yahoo.com

U. Piatkowski

Leibniz-Institut fur Meereswissenschaften,

IFM-GEOMAR, Kiel, Germany

e-mail: upiatkowski@ifm-geomar.de internal seminal receptacle of the majority of the females examined regardless of their maturity state. The seminal receptacle has a unique form and position in this species. The receptacle is a thin-walled sac at the posterior end of the visceral mass that is an outpocketing of, and opens into, the visceropericardial coelom. Spermatangia and sperm from the spermatangia apparently enter into the visceropericardial coelom (which is mostly occupied by the ovary) from the seminal receptacle indicating that ova are fertilised internally, a strategy unknown for decapodiform cephalopods (squid and cuttlefish), but present in most octopods. Fecundity of Heteroteuthis dispar $(1,100-1,300$ oocytes) is much higher than in other sepiolids whereas the egg size (mean max. length $\sim 1.6 \mathrm{~mm}$ ) is the smallest within the family. Spawning is continuous (sensu Rocha et al. in Biol Rev 76:291-304, 2001). These and other reproductive traits are discussed as being adaptations to an oceanic lifestyle.

\section{Introduction}

Small cephalopods of the genus Heteroteuthis are the most pelagic members in the family Sepiolidae.

Heteroteuthis dispar (Rüppell, 1844) is a widely distributed species in the Northern Atlantic and Mediterranean Sea; although a few records are known from the western Indian Ocean and East Pacific (Jereb and Roper 2005).

The species seems to be widely distributed throughout the watercolumn. In two studies performed in the Aegean Sea, $H$. dispar was found to be the most common cephalopod in pelagic samplings up to $650 \mathrm{~m}$ of depth (Salman et al. 2003; Lefkaditou et al. 1999). Nesis (1993) found members of the genus Heteroteuthis, although broadly distributed in the open ocean, more common near seamounts 
and submarine ridges. Roper (1974) reported $H$. dispar migrating to the surface at night. In summarising the life history of $H$. dispar, Nesis (1985) stated that eggs are laid on the bottom of the slope (500-1,000 m), and hatchlings ascend to epipelagic layers. Immature $H$. dispar occur at $25-300 \mathrm{~m}$ in the night and at $150-500 \mathrm{~m}$ during the day. Maturing animals gradually descend to deeper waters, and mature $H$. dispar are distributed in near-bottom layers. Spawning occurs on the seabed. The related and possibly conspecific Heteroteuthis hawaiiensis (Berry 1809) primarily occupies depths of $250-350 \mathrm{~m}$ during the day and depths mostly between 150 and $200 \mathrm{~m}$ at night over bottoms depths of about 2,500 m off Hawaii (Young 1977). Numerous mature females of $H$. hawaiiensis were filmed on the ocean floor at a depth of $912 \mathrm{~m}$ near the Ogasawara Islands (Okutani and Tsuchida 2005).

Because of its abundance in the Mediterranean oceanic ecosystem, $H$. dispar has been described as a keystone species (Bello 1997). It is a dominant presence in the stomachs of albacore (Thunnus alalunga) taken from the Adriatic Sea (Bello 1999) and of giant red shrimp (Aristaeomorpha foliacea) from the Strait of Sicily (Bello and Pipitone 2002). $H$. dispar plays also an important role in the diet of benthic bathyal elasmobranchs, such as Galeus melastomus and Etmopterus spinax (Sartor and De Ranieri 1995). Additionally, H. dispar has been found in stomachs of the swordfish (Xiphias gladius) (Bello 1991; Villanueva 1995), Risso's dolphin (Grampus griseus) (Würtz et al. 1992), and the deep-sea shark Centroscymnus coelolepis (Villanueva 1992).

Knowledge on the reproductive biology of $H$. dispar is restricted to scattered observations on small collections. Naef (1923) pointed out that because of the transparent appearance of hatchlings of $H$. dispar, the species is adapted to the pelagic environment from the moment of hatching. Boletzky (1978) described a single egg with embryo of $H$. dispar that had been collected by open bottom trawl (Mediterranean Sea, $540 \mathrm{~m}$ depth). No detailed information on mating, sperm storage, fecundity and spawning pattern is available for $H$. dispar.

Reproductive strategies in cephalopods have proven to be highly variable and flexible. The degree of environmental stability has been proposed to be one of the factors responsible for such a divergence in strategies (Rocha et al. 2001). This paper examines the reproductive adaptations of $H$. dispar and how these adaptations allow it to exist in an oceanic environment.

\section{Material and methods}

During the the MAR-ECO cruise along the Mid-Atlantic Ridge in 2004 aboard the R/V G. O. SARS (Norway),
H. dispar was found to be one of the most abundant species. Collection was done in the North Atlantic between Iceland and the Azores, $41^{\circ} 11^{\prime}-52^{\circ} 34^{\prime} \mathrm{N}$ and $27^{\circ} 57^{\prime}-$ $31^{\circ} 58^{\prime} \mathrm{W}$. The capture of 46 specimens of $H$. dispar was done between 0 and $1,500 \mathrm{~m}$ of depth (although oblique tows could bias the vertical distribution data for this species) over bottom depths ranging between 1,742 and $3,701 \mathrm{~m}$. Sampling gear that caught these specimens included a double-warp macroplankton trawl with five cod ends, referred to here as the Krill trawl, with $6 \times 6-\mathrm{m}^{2}$ mouth opening, $3 \times 3-\mathrm{mm}$ meshes $(6 \mathrm{~mm}$, stretched) from the mouth to the cod end, a length of $45 \mathrm{~m}$ and standard, pelagic-trawl doors for deployment. The second net was a medium sized pelagic fish trawl with three cod ends, called the Åkra trawl, with a vertical opening of 20-35 m, a door spread of $110 \mathrm{~m}$, graded-mesh netting in the wings and body of the net, and a cod-end mesh size of $22 \mathrm{~mm}$ (stretched) (Vecchione et al. submitted). A total of $45 \mathrm{spec}-$ imens were collected using the Åkra-Trawl and another one was collected with the Krill trawl.

All specimens were measured (dorsal mantle length, ML, in $\mathrm{mm}$; body mass, BM in $\mathrm{g}$ ) immediately after being collected and before preservation in $7 \%$ buffered formalinseawater solution. The samples were shipped to the Bergen University Museum where the current study was mainly executed. All dissections were made on preserved specimens. The measurements, including ML and BM, used in this study were all done on the preserved material and the sex of the animals was established after preservation.

Females considered mature had ripe eggs present in the oviduct; no spent animals were found in the collection. Females considered maturing had different-sized, yolk oocytes in the ovary but no ripe ova in the oviduct. Immature females had only pre-vitellogenic oocytes in the ovary. Males considered mature had spermatophores $(\mathrm{Sp})$ in their Needham's sac. In six mature males (13-24.8 mm ML) the following parameters were determined: spermatophore number (Sp no.); maximum spermatophore width ( $\mathrm{SpW}$ ); spermatophore length ( $\mathrm{SpL})$; spermatophore length index (SpLI); spermatophore mass (SpM); sperm mass length index (SMLI); testis mass index (TMI); reproductive system mass index (RSMI). The gonadosomatic index (GSI) was calculated as: the mass of the reproductive system/ body mass $\times 100 \%$.

In nine females of 10.5-23 mm ML all oocytes and ova from the ovary and oviduct were counted and measured along the major axis using a calibrated stereomicroscope ocular micrometer.

One hectocotylised arm, the right arm of the second arm pair, was removed from three mature males, dehydrated in a graded ethanol series, cleared with toluene and embedded in parafin wax. Cross sections of $3 \mu \mathrm{m}$ were mounted on slides and stained with haemotoxylin and eosin. Additionally, 
sections were stained with periodic acidic-Schiff (PAS), for indication of neutral mucopolysaccharides.

\section{Results}

\section{Sexual dimorphism}

No sexual dimorphism in size was found in mature H. dispar (Fig. 1). The mean ML of mature males was $19.3 \pm 3.1 \mathrm{~mm}$ (range 13.7-24.8 $\mathrm{mm}$ ) and the mean BM was $2.9 \pm 1.1 \mathrm{~g}$ (range 1.3-4.9 g). For mature females the mean ML was $20.7 \pm 2.1 \mathrm{~mm}$ (range 16.7-24.9 mm) and the mean $\mathrm{BM}$ was $3.5 \pm 0.7 \mathrm{~g}$ for females (range 2.7$4.8 \mathrm{~g}$ ). However, considerable morphological sexual dimorphism exists in the structure of the brachial crown (Fig. 2). Males have two greatly enlarged suckers (diameter $=2.2-$ $2.5 \mathrm{~mm}$, next largest sucker $=0.8 \mathrm{~mm}$ ) on each arm of the third pair, as well as modifications of the right arm of the first and second pair (examined below). Females lack suckers on the distal third of arms of the first pair and the distal half of arms of the second pair.

\section{Male reproductive system}

The male reproductive system consisted of a testis, a spermatophoric complex of organs and two hectocotylised arms. The testis was situated posterodorsally in the visceropericardial coelom (VPC) and had a relative weight of 0.9 $5.0 \%$ of the total body mass in mature males $(n=6)$. The spermatophoric complex covered the testis ventrally. The mass of the reproductive system as percentage of BM in mature males was $6.2-9.3 \%(n=6)$. The vas deferens of $H$. dispar was irregularly coiled and, near its origin at the VPC, it expanded into a distinct ampulla. The spermato-

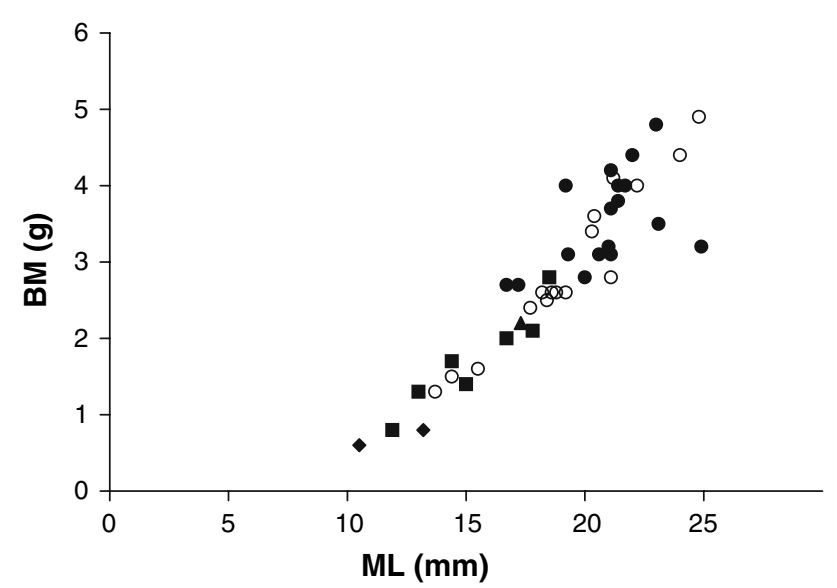

Fig. 1 Heteroteuthis dispar. Mantle length and body mass for mature males (open circle); maturing unmated females (filled diamond); maturing mated females (filled square); mature unmated females (filled triangle) and mature mated females (filled circle)

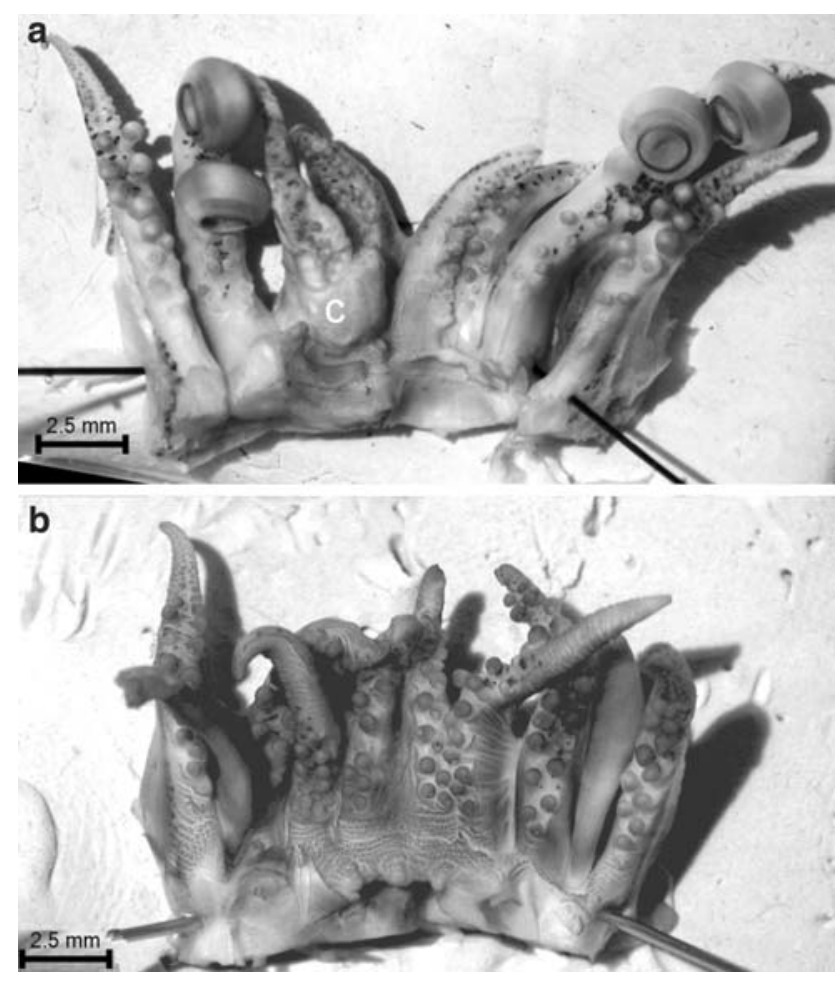

Fig. 2 Heteroteuthis dispar. Oral view of the arm crowns of a male (a) and female (b) showing the enlarged suckers on the arm pair three and the hectocotylised left arm of arm pair one and two in males, and the bare tips of arm pair two of the female. The cushion (c) of the hectocotylus is also shown

phoric complex had six consecutive glands that contributed to the formation of the spermatophores. Spermatophores were stored in the Needham's sac, which was small and had a narrow opening at the base of the left gill. It contained up to five spermatophores. The smallest spermatophore $(\mathrm{SpL}$ $5.6 \mathrm{~mm}$; SpW $0.9 \mathrm{~mm}$ ) was found in the smallest male (ML $13 \mathrm{~mm}$ ) and the largest spermatophores (SpL 7.9-8.6 mm; SpW $2 \mathrm{~mm}$ ) in the largest male (ML $24.8 \mathrm{~mm}$ ). SpM ranged between 0.002 and $0.04 \mathrm{~g}$ (Table 1). The spermatophores (Fig. 3) lie in the Needham's sac with their aboral ends directed toward the penial opening. The ejaculatory apparatus of the spermatophore was smaller than the sperm mass and was tightly coiled orally with a large, single loop at the aboral end. The aboral part of the ejaculatory apparatus, unlike the oral part, was opaque yellowish, and presumably consisted of the cement body. The ejaculatory apparatus including the cement body occupied one third of the total spermatophore length. The large sperm mass consisted of approximately eight coils and occupied the remaining two third of the spermatophore length. The ejaculated spermatophore, the spermatangium, had a simple structure and a slender open end (Fig. 3).

The right arm of the first and second pair contained numerous glandular structures. Seemingly these arms acted as hectocotyli and assisted the transfer of spermatophores. 
Table 1 Data on the male reproductive system of Heteroteuthis dispar

\begin{tabular}{llllllll}
\hline ML $(\mathrm{mm})$ & BM $(\mathrm{g})$ & TMI $(\% \mathrm{BM})$ & RSMI $(\% \mathrm{BM})$ & Sp no. & SpL $(\mathrm{mm})$ & SpW $(\mathrm{mm})$ & Sp mass $(\mathrm{g})$ \\
\hline 24.8 & 4.9 & 1.1 & 6.9 & 5 & $7.9-8.6$ & 2 & $0.02-0.028$ \\
13 & 1.3 & 5.5 & 8.1 & 1 & 5.6 & 0.9 & 0.002 \\
13.7 & 1.3 & 3.7 & 7.4 & 1 & 7.2 & 0.019 \\
21.1 & 2.8 & 2.9 & 6.2 & $6.1-7.3$ & 2 & $0.014-0.015$ \\
24 & 4.4 & 0.9 & 9.3 & 3 & 8 & 2 & $0.02-0.04$ \\
21.1 & 4.1 & 5.4 & 6.8 & 5 & 2 & $0.02-0.03$ \\
\hline
\end{tabular}

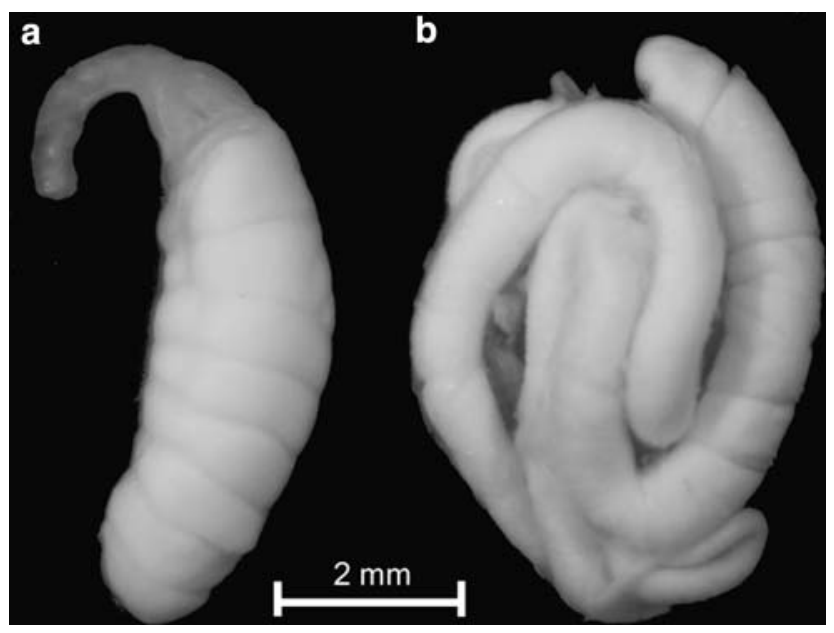

Fig. 3 Heteroteuthis dispar. Spermatophore (a) and spermatangium (b)

At the base of the second right arm a cushion was present (Fig. 2). The longitudinal section of the cushion showed presumably glandular tissue (PAS positive) with loose granules and granules present within vesicles within basal cytoplasm (Fig. 4).

The lateral glands (PAS positive) of the right arm of the second arm pair had numerous small granules present in some large cells lining the lumen of the glands. The cells had virtually lost all of their cytoplasm. The lumens of the glands were also filled with numerous uniform granules (Fig. 4).

\section{Female reproductive system}

The female reproductive system consisted of the ovary, the oviduct, oviducal gland, nidamental glands, accessory nidamental glands and a seminal receptacle. A wide range of oocyte sizes were present in the ovary (oocyte size range: $0.1-1.9 \mathrm{~mm}$; ripe ova size range: $1.3-1.9 \mathrm{~mm}$ ). There were no visible signs of cell division inside the oviductal ova. The oviduct had a small doughnut shaped oviducal gland (maximum width $\sim 2.5 \mathrm{~mm}$ ) and a distal oviduct which extended approximately $2.5 \mathrm{~mm}$ from the oviducal gland (Fig. 5). The external opening of the oviduct in both mature and maturing females was rugose and approximately $1 \mathrm{~mm}$ wide. The opening of the proximal oviduct into the VPC lay on the left side, which was the same side as the opening of the seminal receptacle (see below).

The majority (88\%) of the females had mated (Fig. 1), and carried a large sperm mass (sometimes visibly consisting of more then one spermatangium) in the posteriorly positioned seminal receptacle. The spermatangium was a simple, elongated, irregularly-coiled sperm mass, with a broad end and a narrow opposite end, enveloped in a membrane (Fig. 3). The weight of the sperm present in the receptacle ranged from 0.01 to $0.09 \mathrm{~g}$ (up to $3.4 \%$ of female $\mathrm{BM})$. Since the weight of spermatophores ranged from 0.002 to $0.04 \mathrm{~g}$, presumably more than one spermatangium can be deposited in the receptacle even when they cannot be visibly distinguished.

The seminal receptacle was the most unusual aspect of the female reproductive system (Figs. 5, 6). It was a relatively large sac situated at the posterior end of the visceral mass where, when full, could expand over the ovary, part of the nidamental glands and much of the oviduct. The seminal receptacle seemed to have only one opening and that was to the visceropericardial coelom (VPC) (and therefore the ovary) (Fig. 6). The opening was a wide, short canal at the anteroventral end of the receptacle (Fig. 7). This short canal had radiating folds at both ends and a slight taper with the narrower opening at the VPC. In three cases, a spermatangium was seen with the slender aboral open side in the VPC and the other side inside the receptacle (Fig. 6). In another case one spermatangium was found inside the receptacle while another spermatangium was completely inside the VPC with oocytes and ova clustered around the spermatangium (Fig. 7).

The nidamental glands are $7 \mathrm{~mm}$ in length and $4 \mathrm{~mm}$ in width in the largest female while only $2.7 \mathrm{~mm}$ in length and $1 \mathrm{~mm}$ wide in the smallest mated female. The accessory nidamental glands lay anterior to and were partially covered by the nidamental glands (Fig. 5). The glands were fused to one another in the midline to form a circular structure from which thick plate-like lamellae projected. With onset of maturity the nidamental glands grew and started covering the accessory nidamental glands.

All but one mature females were mated (Fig. 1). Of the nine maturing animals only two were not mated with the 
Fig. 4 Heteroteuthis dispar. Longitudinal sections through the hectocotylised left arm of arm pair two showing (a) the proximal cushion and a detail of glandular tissue in the cushion (b). The lateral glands and a sucker (c) detail of the lateral glands showing uniform granules in lumen of the gland (d) with the opening to exterior indicated by an arrow
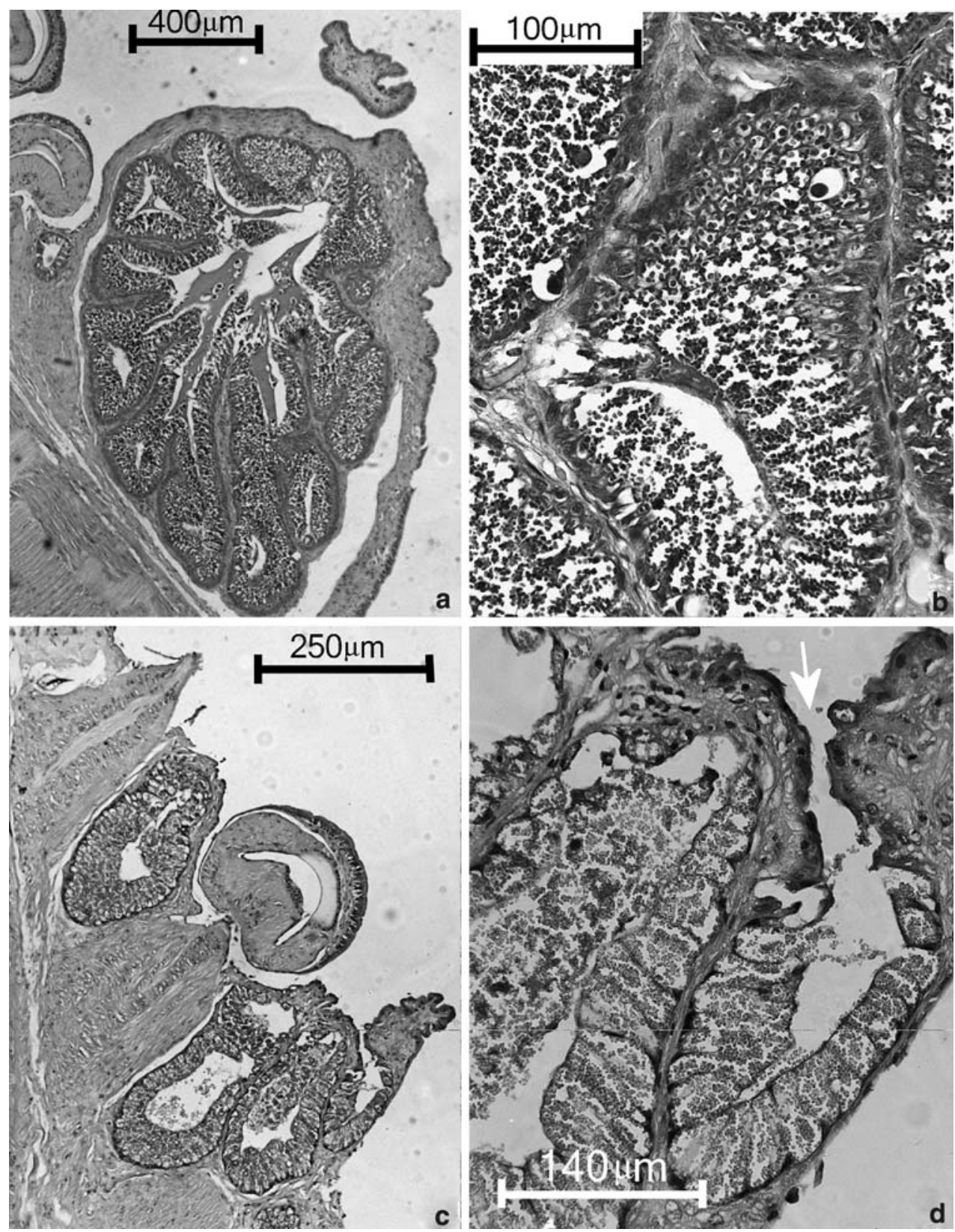

smallest mated female being approximately half the size of the largest mated mature female. Mated females and a few males had large sucker marks (diameter $=2-2.7 \mathrm{~mm}$ ) on the anterolateral surfaces of the mantle.

Fecundity and spawning pattern

Ovulation in H.dispar was asynchronous with the oocyte stock being represented by eggs at different stages of protoplasmic growth and yolk accumulation. The bulk of the oocyte stock in immature females was represented by previtellogenic oocytes of $0.1-0.2 \mathrm{~mm}$. During ovarian growth, oocytes of $0.1 \mathrm{~mm}$ gradually disappeared, and the predominating oocyte size was $0.3 \mathrm{~mm}$ in mature animals (Fig. 8).
Eggs probably ovulated one by one and accumulated in the oviduct. The number of oviducal eggs could be as high as 185 , which represented up to $20 \%$ of the total number of oocytes. The total no. of oocytes varied between 631 and 1,304 eggs, being about $1,100-1,300$ in pre-spawning animals (Table 2).

\section{Discussion}

Mating and sperm transfer

The male reproductive system of $H$. dispar differs from that in other genera of sepiolids in the morphology and the 
Fig. 5 Heteroteuthis dispar.

Mantle cavity of (a) an unmated maturing female, (b) a mated maturing female, (c) a mated mature female with the posterior mantle in place, and (d) a mated mature female with the posterior mantle folded backwards. Oviduct opening (odo), oviducal gland (odg), oviduct (od), nidamental glands (ng) and seminal receptacle $(\mathrm{sr})$
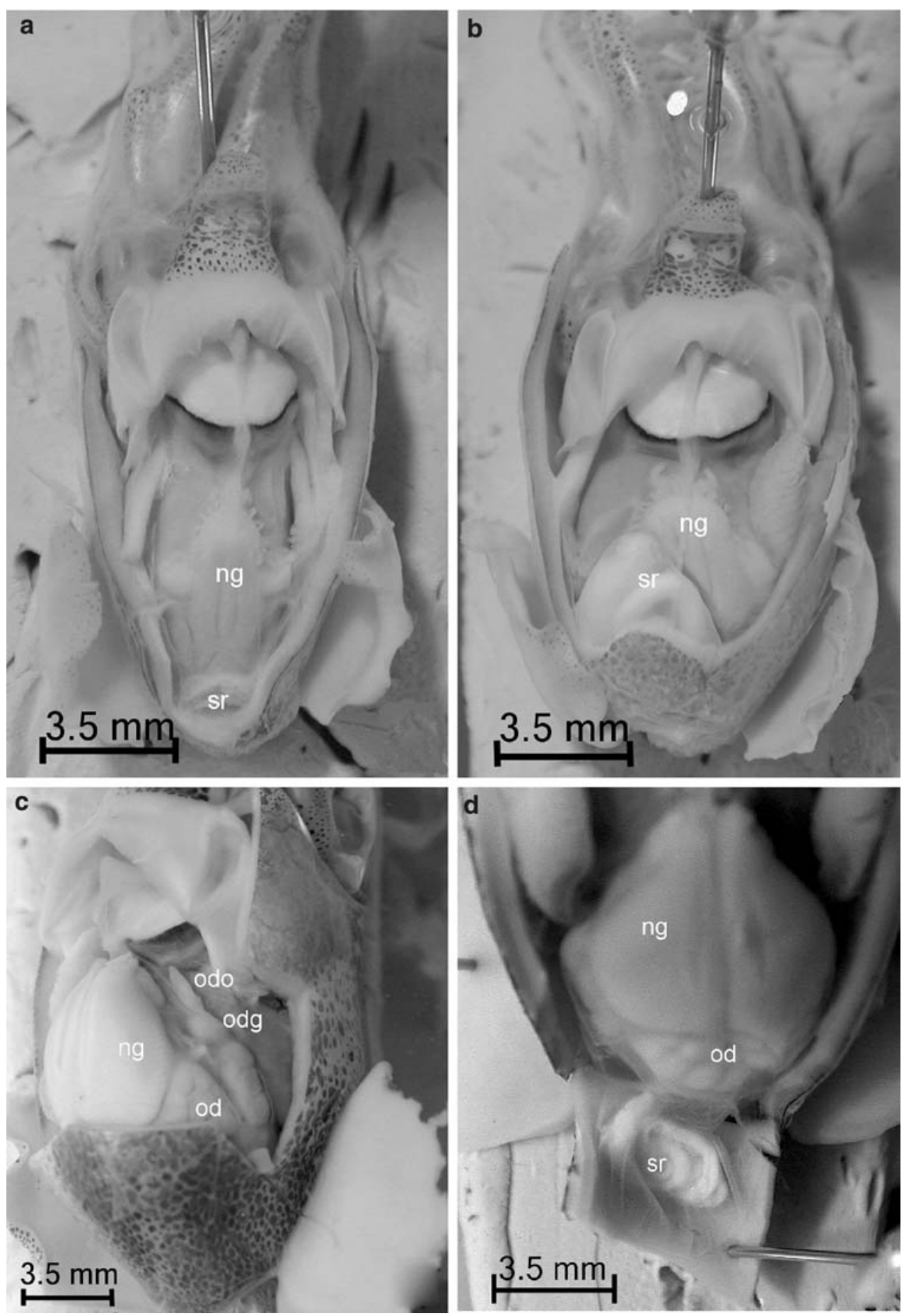

position of the hectocotylus as well as the size and morphology of the spermatophore (Table 3). The glandular tissue on the hectocotylus probably aids spermatophore transfer or stimulation of the female but the nature of the secretion of the glands and how it is used are not known. Similar glandular structures are also present on both first arms of Rossia macrosoma (pers. obs. Hoving) and species of Stoloteuthis and Sepiolina (Young et al. 2004).
Compared to other sepiolids, $H$. dispar has the widest spermatophores, the highest value for the relative length of the sperm mass inside the spermatophore and the fewest spermatophores inside the Needham's sac (Table 3). The morphology of the spermatophore is very simple and the cement body could hardly be distinguished from the ejaculatory apparatus. The rather simple morphology of $H$. dispar spermatophore presumably is due to the specialised 
Fig. 6 Heteroteuthis dispar.

a Mated immature female with a spermatangium in seminal receptacle, $\mathbf{b}$ same female but with the ventral membrane of the seminal receptacle almost completely removed, showing part of the spermatangium going in the opening to the VPC, $\mathbf{c}$ the same as former but with dorsal membrane of the seminal receptacle removed showing the ovary in the VPC and the oviduct, $\mathbf{d}$ the same as former but with dorsal membrame folded backwards showing one coiled side of the spermatangium inside the VPC. Seminal receptacle (sr), nidamental glands (ng), spermatangium (sp), mantle wall (mw), ovary (ov), oviduct (od) and stomach (st)
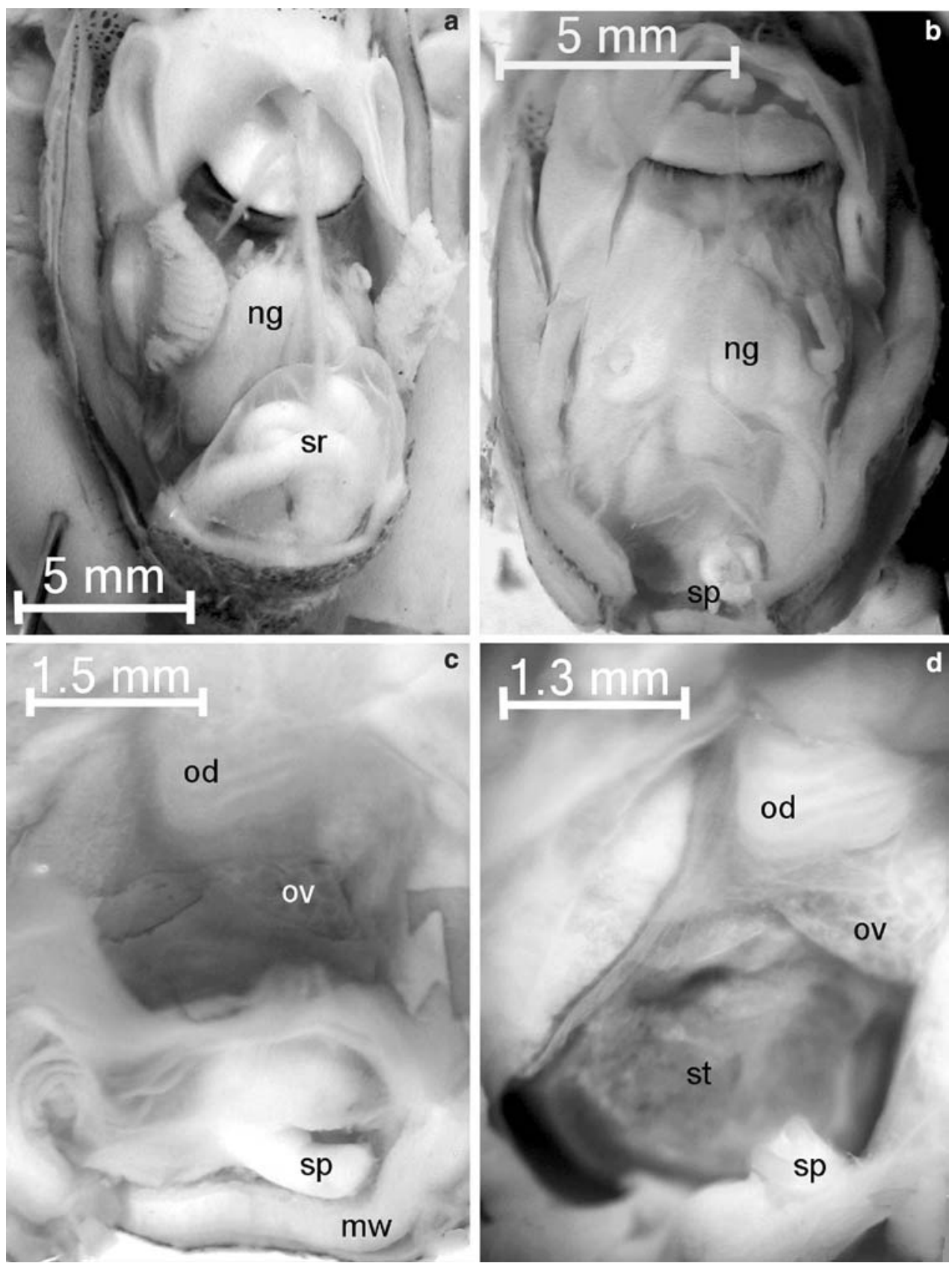

seminal receptacle of females. The spermatophore does not need elaborate structures that would secure the spermatangium into the rugose wall of the bursa copulatrix like Sepiola spp. and Sepietta spp. (Bello 1995) or would enable the spermatophore to implant into the tissue of the female like in Rossia moelleri (Zumholz and Frandsen 2007) and Stoloteuthis leucoptera (Villanueva and Sanchez 1993).

In addition, the deposition of spermatangia on the bursa copulatrix or similar seminal receptacles risks improper attachment and loss of sperm. Because $H$. dispar has an internal seminal receptacle where attachment is unnecessary, the successful transfer of sperm seems secure after mating and male $H$. dispar can invest more sperm per spermatophore.

Sucker scars, present on the head and mantle in both females and males match the enlarged suckers on the third arms of the male, which indicates that these arms are used to hold the female during mating (Orsi-Relini 1995). The presence of scars on males may be due to agonistic behaviour between competing males, or males may capture any specimens within their reach regardless their sex and only start mating when the captured specimen is a female. Racovitza (1894) described the mating behaviour of Sepiola atlantica; for this species the male grasps the female and 


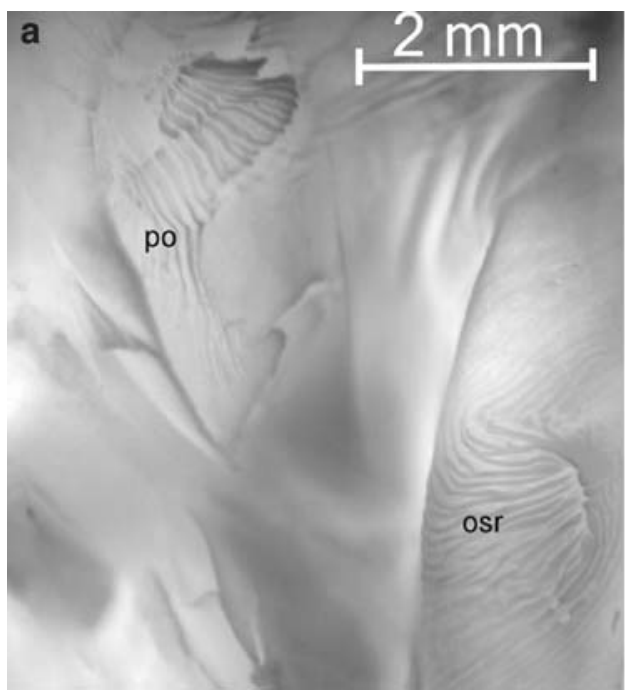

Fig. 7 Heteroteuthis dispar. a Opening of the seminal receptacle and the oviduct into the visceropericardial coelome, stained with methylene blue; the ovary and free ova have been removed (view from the VPC). $\mathbf{b}$ Lateral view of a mated female with part of a spermatagium inside the seminal receptacle and another part inside the VPC. The ven-
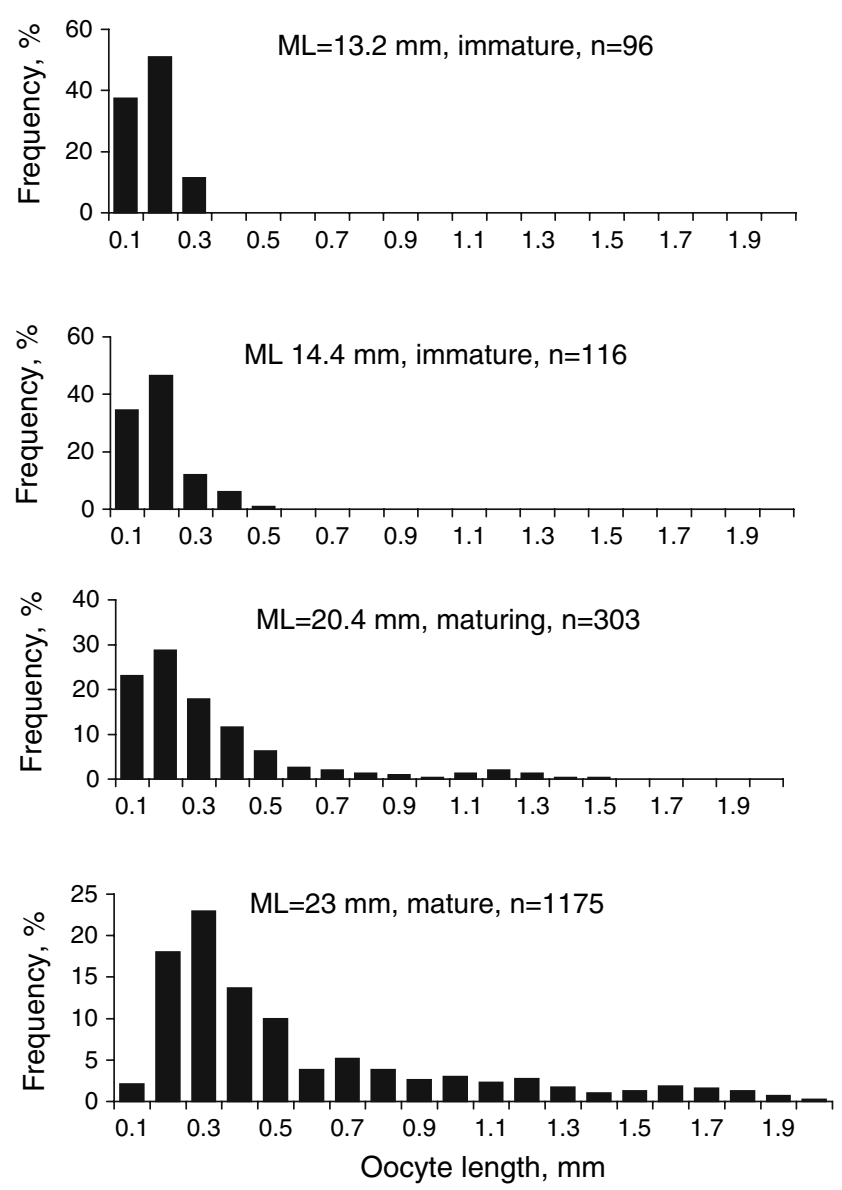

Fig. 8 Oocyte length frequency distributions for four females of Heteroteuthis dispar (ML range13.2-23 $\mathrm{mm}$ )

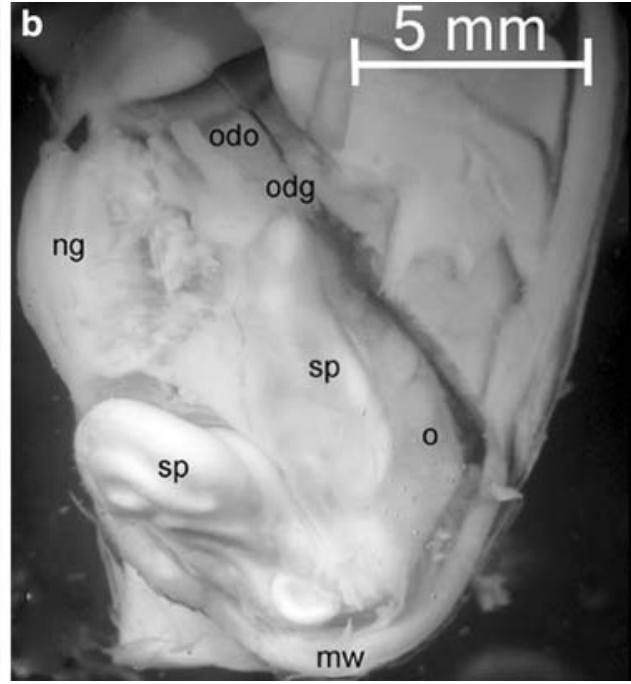

tral membrane of the seminal receptacle has been removed. Proximal oviduct opening (po), opening seminal receptacle (osr), spermatangium (sp), mantle wall (mw), ova (o), oviduct opening (odo), oviducal gland opening (odg) and nidamental gland (ng)

turns her over, ventral side up. Then he holds the female with his third arms around her neck while he deposits with his hectocotylus (left first arm) the spermatophores onto the bursa copulatrix on the left side of her body. Although the sucker scars in $H$. dispar could be explained by a similar intense stranglehold, the mating position may be different since the hectocotylus of $H$. dispar is positioned on the right side and the opening of the oviduct is positioned on the left side.

\section{Sperm storage and fertilisation}

The sepiolin genera Sepietta, Sepiola and Euprymna have a bursa copulatrix (Table 4), which is a complex enlargement of the distal oviduct where spermatangia attach. In rossiins spermatangia either attach to their head and mantle or they or to a ridged area near the opening of the oviduct (Table 4). Sperm storage for other heteroteuthins is only known for S. leucoptera and this species carries implanted spermatangia in its arm and head region (Table 4). The posterior seminal sac of $H$. dispar is a closed and specialised organ and an outpocketing of the VPC and its structure has no known counterpart in any other sepiolid.

Fertilisation in the majority of cephalopods (except most octopods) is external in the sense that eggs are fertilised outside of the body (Hanlon and Messenger 1996). However, in squid and cuttlefish (including sepiolids) fertilisation occurs either within the volume formed by the arms or in the mantle cavity near the oviduct, prior to egg deposition (Hanlon and Messenger 1996). Because in the latter 
Table 2 Fecundity data of Heteroteuthis dispar

\begin{tabular}{|c|c|c|c|c|c|c|c|}
\hline $\mathrm{ML}(\mathrm{mm})$ & $\begin{array}{l}\text { Minimum } \\
\text { fecundity }\end{array}$ & $\begin{array}{l}\text { Potential } \\
\text { fecundity }\end{array}$ & $\begin{array}{l}\text { Maturity } \\
\text { stage }\end{array}$ & $\begin{array}{l}\text { No of oocytes } \\
\text { in ovary }\end{array}$ & $\begin{array}{l}\text { No of ova } \\
\text { in oviduct }\end{array}$ & $\begin{array}{l}\text { Empty } \\
\text { follicles }\end{array}$ & $\begin{array}{l}\text { Ripe egg } \\
\text { size }(\mathrm{mm})\end{array}$ \\
\hline 14.4 & & 1,107 & Immature & 1,107 & & & \\
\hline 10.5 & & $\sim 1,200$ & Immature & $\sim 1,200$ & & & \\
\hline 20.4 & & 1,219 & Maturing & 1,219 & & & \\
\hline 17.3 & 946 & & Mature & 903 & 43 & 12 & $1.4-1.9$ \\
\hline 21.1 & 1,304 & & Mature & 1,119 & 185 & 100 & $1.2-1.8$ \\
\hline 23 & 1,233 & & Mature & 1,175 & 58 & 38 & $1.3-1.9$ \\
\hline 18 & 894 & & Mature & 736 & 158 & 54 & $1.3-1.9$ \\
\hline 20.1 & 717 & & Mature & 631 & 86 & 34 & $1.1-1.9$ \\
\hline 20 & 995 & & Mature & 855 & 140 & 51 & $1.3-1.8$ \\
\hline
\end{tabular}

Table 3 Information on the male reproductive biology of several sepiolids

\begin{tabular}{|c|c|c|c|c|c|c|c|c|c|}
\hline Subfamily & Species & $\begin{array}{l}\operatorname{maxML} \\
(\mathrm{mm})\end{array}$ & $\mathrm{SpL}(\mathrm{mm})$ & $\begin{array}{l}\text { SpLI } \\
\text { (\% ML) }\end{array}$ & $\mathrm{SpW}(\mathrm{mm})$ & $\begin{array}{l}\text { SMLI } \\
(\% \text { SpL })\end{array}$ & Sp no. & Hectocotylus & Reference \\
\hline \multirow[t]{7}{*}{ Rossiinae } & Semirossia patagonica & 32 & $5.6-25.1$ & $22.4-86.6$ & & & $13-229$ & LI & Pers. obs. Laptikhovsky \\
\hline & Neorossia leptodons & 42 & & $26.8-41.2$ & & & & LRI & Reid 1991 \\
\hline & Neorossia caroli & 50 & $12.0-13.0$ & $36.5-41.2$ & & & $\sim 40$ & LRI & $\begin{array}{l}\text { Reid 1991; } \\
\quad \text { Cuccu et al. } 2007\end{array}$ \\
\hline & Rossia australis & 33.8 & & $20-35$ & $0.45-0.74$ & 60 & & LRI & Reid 1991 \\
\hline & Rossia pacifica & 45 & 10 & 22.2 & & & & LRI & Fields and Thompson 1976 \\
\hline & Rossia moelleri & & $9.2-12.7$ & & 0.8 & 50 & $19-56$ & LRI & Pers. obs. Hoving \\
\hline & Rossia macrosoma & & 20 & & & & 60 & LRI & $\begin{array}{l}\text { Mangold-Wirz 1963; } \\
\text { Racovitza } 1894\end{array}$ \\
\hline \multirow[t]{6}{*}{ Sepiolinae } & Euprymna tasmanica & 33.5 & $11.7-14.4$ & $35-43$ & 0.9 & 30 & $15-106$ & LI & Norman and Lu 1997 \\
\hline & Sepietta oweniana & 35 & $4.0-9.5$ & $11.4-27.1$ & & & $87-824$ & LI & $\begin{array}{l}\text { Mangold-Wirz 1963; } \\
\quad \text { Salman } 1998\end{array}$ \\
\hline & Sepiola atlantica & 21 & $6.5-10$ & $31-48$ & & & $59-338$ & LI & Yau and Boyle 1996 \\
\hline & Sepiola intermedia & 26 & $8.4-10.4$ & $32-40$ & & & $98-217$ & LI & Salman and Onsoy 2004 \\
\hline & Sepiola robusta & 28 & $5.8-8.2$ & $23-33$ & & & $109-386$ & LI & $\begin{array}{l}\text { Boletzky 1983; } \\
\quad \text { Salman and Onsoy } 2004\end{array}$ \\
\hline & Sepiola steenstrupiana & 18 & $3.5-7$ & $19.4-38.9$ & & & $13-377$ & LI & Salman and Onsoy 2004 \\
\hline \multirow[t]{3}{*}{ Heteroteuthinae } & Heteroteuthis dispar & 24.8 & 8 & 32.2 & 2 & 67 & 5 & RI,II & \\
\hline & Stoloteuthis leucoptera & 19 & $2.8-3$ & $14.7-15.7$ & & & $>40$ & LRI & $\begin{array}{l}\text { Villanueva and } \\
\text { Sanchez } 1993\end{array}$ \\
\hline & & & & & & & & & Orsi Relini and Massi 1991 \\
\hline
\end{tabular}

All structures that involve a modification of the distal oviduct are here called a bursa copulatrix

case fertilisation occurs within the mantle cavity, this type is sometimes referred to as internal fertilisation while it should be termed "confined" external fertilisation (Naud and Havenhand 2006). Internal fertilisation, where spermatozoa enter into the body (oviduct) and fertilisation presumably occurs in the oviduct as the egg passes, is unknown for any decapod cephalopod but is known for the Octopodidae; in the benthic octopod genus Eledone spermatophores even enter the ovary (Fort 1937).

Presumably the spermatangium in $H$. dispar enters the internal seminal receptacle after passing through the oviduct and VPC. How this happens is not entirely clear as ova in the VPC and/or oviduct could pose a barrier. Most spermatangia were found in the receptacle, none were observed inside the oviduct but one was found entirely within the VPC and one spanning the canal between the VPC and the receptacle. Also a sperm mass (i.e., not in a spermatangium) was found in the VPC. Sperm are apparently released from spermatangia into the VPC and fertilization may occur there or in the oviduct. However, no oviducal ova were found to unequivocally be fertilized. Like in fish eggs, the perivitelline space probably does not 
Table 4 Information on the female reproductive biology of several sepiolids

\begin{tabular}{|c|c|c|c|c|c|c|}
\hline Subfamily & Species & $\begin{array}{l}\text { Ovum } \\
\text { length }(\mathrm{mm})\end{array}$ & $\begin{array}{l}\text { Potential } \\
\text { fecundity }\end{array}$ & $\begin{array}{l}\text { Batch } \\
\text { fecundity }\end{array}$ & Sperm storage & Reference \\
\hline \multirow[t]{8}{*}{ Rossiinae } & Semirossia patagonica & $3.4-5$ & $527-766$ & & $\begin{array}{l}\text { Implantation near } \\
\text { oviducal opening }\end{array}$ & Pers. obs. Laptikhovsky \\
\hline & Neorossia leptodons & 11.7 & & & Bursa copulatrix & Reid 1991 \\
\hline & Neorossia caroli & $9-9.9$ & $20-611$ & 13 & $\begin{array}{l}\text { Implantation in } \\
\text { mantle near oviduct }\end{array}$ & Reid 1991; Cuccu et al. 2007 \\
\hline & Rossia australis & 9.5 & & & Bursa copulatrix & Reid 1991 \\
\hline & Rossia pacifica & 9 & & & $\begin{array}{l}\text { Ridged area near } \\
\text { oviduct }\end{array}$ & Fields and Thompson 1976 \\
\hline & Rossia moelleri & $7-9$ & $103-385$ & & $\begin{array}{l}\text { Implantation in } \\
\text { head and mantle }\end{array}$ & $\begin{array}{l}\text { Pers. obs. Hoving; Zumholz } \\
\text { and Frandsen } 2006\end{array}$ \\
\hline & \multirow[t]{2}{*}{ Rossia macrosoma } & \multirow[t]{2}{*}{$7-8$} & & 36 & $\begin{array}{l}\text { Ridged area near } \\
\text { oviduct }\end{array}$ & $\begin{array}{l}\text { Mangold-Wirz 1963; } \\
\text { Racovitza 1894; } \\
\text { Gabel-Deickert } 1995\end{array}$ \\
\hline & & & & & $\begin{array}{l}\text { Implantation in } \\
\text { head and mantle }\end{array}$ & Pers. obs. Hoving \\
\hline \multirow[t]{9}{*}{ Sepiolinae } & Euprymna tasmanica & $2.8-3.7$ & & & Bursa copulatrix & Norman and Lu 1997 \\
\hline & Sepietta oweniana & $1.4-3.4$ & $58-236$ & 30 & Bursa copulatrix & $\begin{array}{l}\text { Mangold-Wirz 1963; Salman 1998; } \\
\text { Gabel-Deickert } 1995\end{array}$ \\
\hline & Sepiola affinis & & & $1-117$ & Bursa copulatrix & Gabel-Deickert 1995; Bello 1995 \\
\hline & Sepiola rondeleti & & & $3-106$ & Bursa copulatrix & Gabel-Deickert 1995; Bello 1995 \\
\hline & Sepietta obscura & & & $2-176$ & Bursa copulatrix & Gabel-Deickert 1995; Bello 1995 \\
\hline & Sepiola atlantica & $2.5-3$ & & & Bursa copulatrix & Yau and Boyle 1996 \\
\hline & Sepiola intermedia & $2.2-2.9$ & $111-407$ & $6-100$ & Bursa copulatrix & $\begin{array}{l}\text { Salman and Onsoy 2004; } \\
\quad \text { Gabel-Deickert } 1995\end{array}$ \\
\hline & Sepiola robusta & 2.2 & $117-245$ & 33 & Bursa copulatrix & $\begin{array}{l}\text { Boletzky 1983; Salman and } \\
\quad \text { Onsoy 2004; Gabel-Deickert } 1995\end{array}$ \\
\hline & Sepiola steenstrupiana & $2.8-4.8$ & $163-191$ & & Bursa copulatrix & Salman and Onsoy 2004 \\
\hline \multirow[t]{2}{*}{ Heteroteuthinae } & Heteroteuthis dispar & $1.1-1.9$ & $717-1233$ & & Seminal receptacle & \\
\hline & Stoloteuthis leucoptera & 2.8 & & & $\begin{array}{l}\text { Implantation in } \\
\text { head and arm region }\end{array}$ & Villanueva and Sanchez 1993 \\
\hline
\end{tabular}

$L I$ left arm of the first pair, $R I$ right arm of the first pair, $R I I$ right arm of the second pair and $L R I$ left and right arm of the first pair

appear unless the egg is released into the water (Hisaoka 1958).

Spawning and fecundity

H. dispar is characterised by asynchronous vitellogenesis. The oocyte stock consists of oocytes at different stages of yolk accumulation but mostly of small pre-vitellogenic and early vitellogenic oocytes. The number of advanced yolk oocytes is negligible in respect to the total fecundity, which indicates that spawning is intermittent. This feature combined with presumable growth during a long reproductive period makes us conclude that spawning is "continuous" (sensu Rocha et al. 2001).

Where known, all sepiolids are intermittent spawners (Table 4). However, compared to other representatives of the family, $H$. dispar has higher fecundity and relatively small egg size (7-9\% ML) (Table 4). Fecundity of $H$. dispar is about 5-10 times higher than that in the nectobenthic neritic sepiolins Sepietta owienana; Sepiola intermedia; Sepiola robusta; Sepiola steenstrupiana and neritic and bathyal rossiins Semirossia patagonica, Rossia moelleri and Neorossia caroli (Table 4).

\section{A sepiolid reproductive adaptation to an oceanic lifestyle}

Heteroteuthis dispar reproductively differentiates itself from other sepiolids by (1) having the smallest egg size, (2) having the highest fecundity, (3) having spermatophores that are relatively the largest with the highest relative sperm mass but with the fewest numbers and (4) apparent internal fertilisation (Tables 3, 4).

The female characteristics of $H$. dispar are typical for 'oceanisation'. Oceanisation is an evolutionary process 
occurring within a cephalopod or fish family when it undergoes expansion from initial shelf biotopes to the open ocean (Nigmatullin and Laptikhovsky 1994). Reproductive adaptations associated with oceanisation involve an increase in fecundity and a decrease in egg size. This pattern is seen in ommastrephid squids (Nigmatullin and Laptikhovsky 1994) and scombroid fishes (Alexeev and Alexeeva 1981).

Presumably dispersal by ocean currents into unfavourable environments, high predation and low food abundance cause high mortality in young cephalopod and fish in the open ocean resulting in evolutionary pressure to increase fecundity and thus to spread the risk of reproductive failure. On the other hand, the high fecundity and intermittent spawning over an extended period allows $H$. dispar to take advantage of any temporary excess production in the ecosystem of the open ocean (Rocha et al. 2001).

We suppose that the large spermatophores in $H$. dispar is a strategy to minimise the number of mating events needed in a three dimensional environment, in order to reduce the risk of predation during courtship and copulation, and/or ensure sufficient availability of sperm as mating encounters between the sexes may be limited. The latter possibility is supported by the presence of spermatangia in immature females. A low encounter rate may be due to sexual differences in vertical or horizontal distribution or by a low density of individuals.

The reproductive strategy of $H$. dispar is a good example of the high flexibility found in cephalopod reproductive strategies.

\begin{abstract}
Acknowledgments The valuable help of and the fruitful discussions with Dr. R.E. Young during dissections on $H$. dispar in Bergen Museum are greatly appreciated. Also comments by Dr. R.E. Young on an earlier draft of this paper greatly improved the quality of the manuscript. Mar-Eco and the Census of Marine Life are thanked for financial support during the workshop in Bergen University Museum and for the collection of the animals. The staff of the Bergen Museum of Natural History is thanked for their help during the workshop. Mr. Odo Wieringa of the pathology and histology department (University Medical Centre Groningen) is thanked for the preparation of histological sections of the hectocotylus. Deniz Haydar is thanked for her help with the illustrations and the English language.
\end{abstract}

Open Access This article is distributed under the terms of the Creative Commons Attribution Noncommercial License which permits any noncommercial use, distribution, and reproduction in any medium, provided the original author(s) and source are credited.

\section{References}

Alexeev FE, Alexeeva EI (1981) Some aspects of the reproductive biology in oceanic and neritic tuna (Scombridae) of Tropical Atlantic. Vopr Ihtiol 21(5):853-866 (in Russian)

Bello G (1991) Role of cephalopods in the diet of the swordfish, Xiphias gladius, from the eastern Mediterranean Sea. Bull Mar Sci 49:312-324
Bello G (1995) A key for the identification of the Mediterranean sepiolids (Mollusca: Cephalopoda). Bull Inst Oceanogr Monaco, $\mathrm{n}^{\circ}$ spéc. 16:41-55

Bello G (1997) Teuthophagous predators as collectors of oceanic cephalopods: the case of the Adriatic Sea. Boll Malacol 32:71-78

Bello G (1999) Cephalopods in the diet of albacore, Thunnus Alalunga, from the Adriatic Sea. J Moll Stud 65:233-240

Bello G, Pipitone C (2002) Predation on cephalopods by the giant red shrimp Aristaeomorpha foliacea. J Mar Biol Ass UK 82:213-218

Boletzky Sv (1978) Premières données sur le développement embryonnaire du Sépiolide pelagique Heteroteuthis (Mollusca, Cephalopoda). Haliotis 9:81-84

Boletzky Sv (1983) Sepiola robusta. In: Boyle PR (ed) Cephalopod life cycles. Academic Press, London, pp 53-67

Cuccu D, Mereu M, Cannas R, Follesa MC, Cau A, Jereb P (2007) Egg clutch, sperm reservoirs and fecundity of Neorossia caroli (Cephalopoda: Sepiolidae) from the southern Sardinian sea (west Mediterranean). J Mar Biol Ass UK 87:971-976

Fields WG, Thompson KA (1976) Ultrastructure and functional morphology of spermatozoa of Rossia pacifica (Cephalopoda, Decapoda). Can J Zool 54:908-932

Fort G (1937) Le spérmatophore des Cephalopodes. Étude du spérmatophore d'Eledone cirrhosa Lam. Bull Biol Fr Belg 71:357-373

Gabel-Deickert A (1995) Reproductive patterns in Sepiola affinis and other Sepiolidae (Mollusca, Cephalopoda). Bull Inst Oceanogr Monaco, $\mathrm{n}^{\circ}$ spéc. 16:73-83

Hanlon RT, Messenger JB (eds) (1996) Cephalopod behavior. Cambridge University Press, Cambridge, p 232

Hisaoka KK (1958) Microscopic studies of the teleost chorion. T Am Micros Soc 77:240-243

Lefkaditou E, Papaconstantinou C, Anastasopoulou K (1999) Juvenile cephalopods collected in the midwater macroplankton over a trench in the Aegean Sea (Northeastern Mediterranean). Isr J Zool 45:395-405

Mangold-Wirz K (1963) Contribution a l'étude de Rossia caroli Joubin. Vie Milieu 14:205-224

Naef A (1923) Die Cephalopoden, Systematik. Fauna Flora Golf Neapel 35(1):1-863

Naud MJ, Havenhand JN (2006) Sperm motility and longevity in the giant cuttlefish, Sepia apama (Mollusca: Cephalopoda). Mar Biol 148(3):559-566

Nesis KN (1985) Oceanic cephalopod molluscs. Nauka, Moscow, p 285 (in Russian)

Nesis KN (1993) Cephalopods of seamounts and submarine ridges. In: Okutani T, O'Dor RK, Kubodera T (eds) The recent advances in cephalopod fishery biology. Tokai University Press, Tokyo, pp 365-373

Nigmatullin CM, Laptikhovsky V (1994) Reproductive strategies in the squids of the family Ommastrephidae (preliminary report). Ruthenica 4(1):79-82

Norman M, Lu CC (1997) Redescription of the southern dumpling squid Euprymna tasmanica and a revision of the genus Euprymna (Cephalopoda: Sepiolidae). J Mar Biol Ass UK 77:1109-1137

Okutani T, Tsuchida S (2005) Occurrence and living habit of bathyal bobtail squid, Heteroteuthis hawaiiensis (Cephalopoda: Sepiolidae) from off the Ogasawara Islands, Japan. http://www.tolweb. org/Heteroteuthis/20030

Orsi-Relini L (1995) Notes on midwater collections of Heteroteuthis dispar (Cephalopoda, Sepiolidae). Bull Inst Oceanogr Monaco, n spéc. 16:63-72

Orsi-Relini L, Massi D (1991) The butterfly squid Stoloteuthis leucoptera in the Mediterranean. J Mar Biol Ass UK 71:47-51

Racovitza ÉG (1894) Sur l'accouplement de quelques Céphalopodes Sepiola rondeleti (Leach), Rossia macrosoma (delle Chiaje) et 
Octopus vulgaris (Lam.). C R Hebd Seances Acad Sci Paris Series D 118:722-724

Reid A (1991) Taxonomic review of the Australian Rossiinae (Cephalopoda: Sepiolidae), with a description of a new species, Neorossia leptodons, and redescription of $N$. caroli (Joubin, 1902). Bull Mar Sci 49(3):748-831

Reid A, Jereb P (2005) Family Sepiolidae Leach, 1817. In: Jereb P, Roper CFE (eds) Cephalopods of the world. An annotated and illustrated catalogue of cephalopod species known to date, vol 1(4). Chambered Nautiluses and Sepioids (Nautilidae, Sepiidae, Sepiolidae, Sepiadariidae, Idiosepiidae and Spirulidae). FAO, Rome, pp 153-203

Rocha F, Guerra Á, Gonzales AF (2001) A review of reproductive strategies in cephalopods. Biol Rev 76:291-304

Roper CFE (1974) Vertical and seasonal distribution of pelagic cephalopods in the Mediterranean Sea. Preliminary report. Bull. Am. Malacol. Union, pp 27-30, May 1974

Salman A (1998) Reproductive biology of Sepietta oweniana (Pfeffer, 1908) (Sepiolidae: Cephalopoda) in the Aegean Sea. Sci Mar 62(4):379

Salman A, Katağan T, Benli HA (2003) Vertical distribution and abundance of juvenile cephalopods in the Aegean Sea. Sci Mar 67(2):167-176

Salman A, Önsoy B (2004) Analysis of fecundity of some bobtail squid of the genus Sepiola (Cephalopoda: Sepiolida) in the Aegean Sea (eastern Mediterranean). J Mar Biol Ass UK 84:781-782
Sartor P, De Ranieri S (1995) Heteroteuthis dispar (Ruppell, 1844) (Cephalopoda, Sepiolidae) nella dieta di due selaci batiali nel Mar Tirreno settentrionale. Biol Mar Medit 2(2):517-518

Vecchione M, Young RE, Piatkowski U (2008) Cephalopods of the northern mid-Atlantic Ridge (submitted)

Villanueva R (1992) Deep-sea cephalopods of the north-western Mediterranean: indications of up-slope ontogenetic migration in two bathybenthic species. J Zool 227:267-276

Villanueva R (1995) Distribution and abunandance of bathyal sepiolids (Mollusca: Cephalopoda) in the northwestern Mediterranean. Bull Inst Oceanogr Monaco, $\mathrm{n}^{\circ}$ spéc. 16:19-26

Villanueva R, Sanchez P (1993) Cephalopods of the Benguela Current off Namibia: new additions and considerations on the genus $\mathrm{Lyco}$ teuthis. J Nat Hist 27(1):15-46

Würtz M, Poggi R, Clarke MR (1992) Cephalopods from the stomachs of a Risso's dolphin (Grampus griseus) from the Mediterranean. J Mar Biol Ass UK 72:861-867

Yau C, Boyle PR (1996) Ecology of Sepiola atlantica (Mollusca: Cephalopoda) in the shallow sublittoral zone. J Mar Biol Ass UK 76:733-748

Young RE (1977) Bioluminescent countershading in midwater cephalopods. Proc Zool Soc Lond 38:161-190

Young RE, Roper CFE, Vecchione M (2004) Heteroteuthinae Appellof, $1898 \mathrm{http}: / / \mathrm{www}$. tolweb.org/Heteroteuthinae/20027

Zumholz K, Frandsen R (2006) New information on the life-history of cephalopods off West Greenland. Pol Biol 29:169-178 